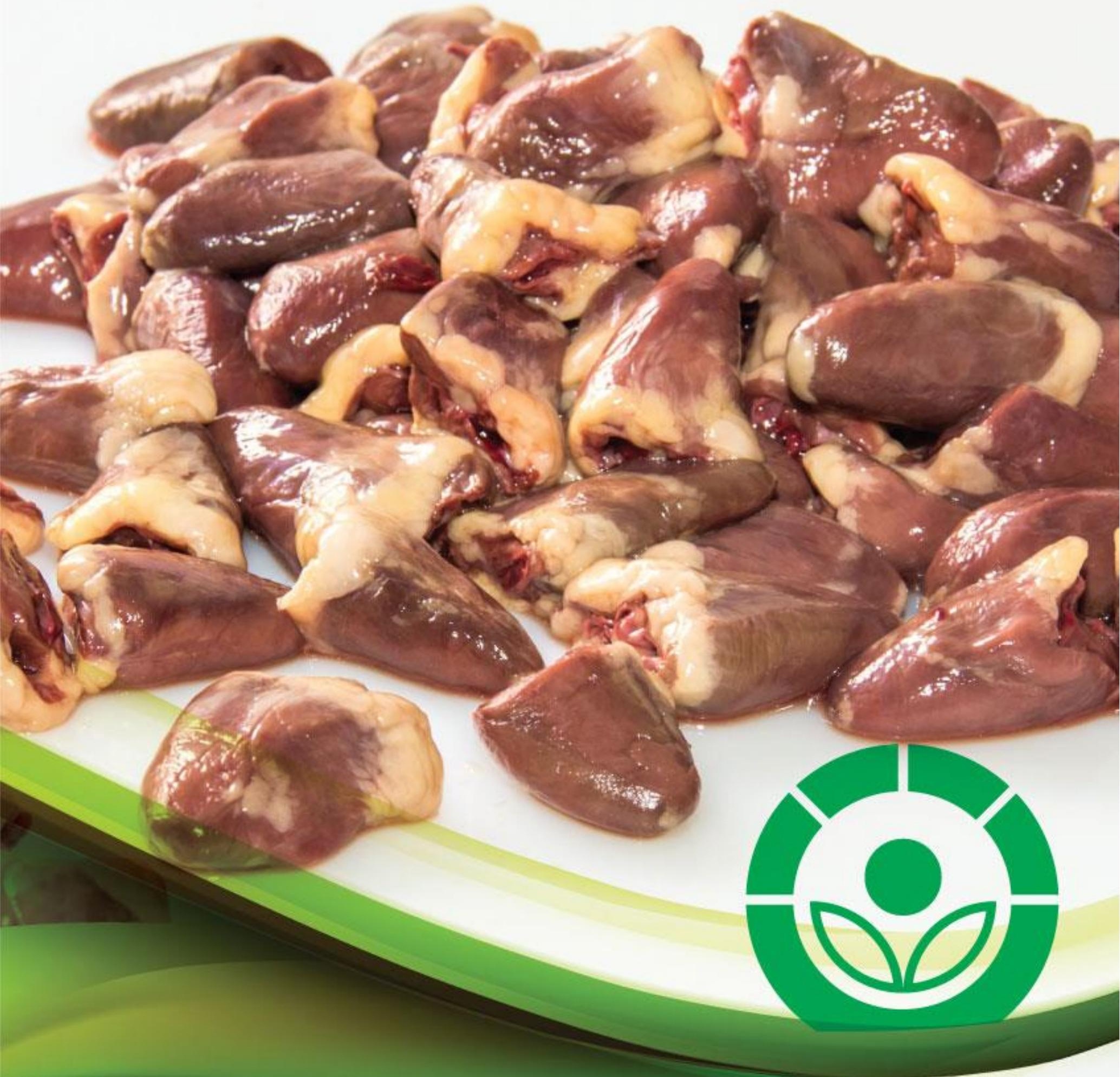

Effect of gama irradiation (Co60) in the control of Enterococci spp. and Escherichia coli in chilled chicken (Gallus gallus) heart

Efeito da irradiação gama (Co60) no controle de Enterococcus spp. $e$ Escherichia coli em coração de frango (Gallus gallus) resfriado

Marta Maria XAVIER, Robson Maia FRANCO, Mauro Carlos Lopes SOUZA

Ana Beatriz Monteiro FONSECA, Wagner Thadeu Cardosos ESTEVES e Sheila da Silva DUQUE 


\title{
Effect of gama irradiation (Co60) in the control of Enterococci spp. and Escherichia coli in chilled chicken (Gallus gallus) heart
}

\author{
Efeito da irradiação gama (Co60) no controle de Enterococcus spp. e Escherichia \\ coli em coração de frango (Gallus gallus) resfriado
}

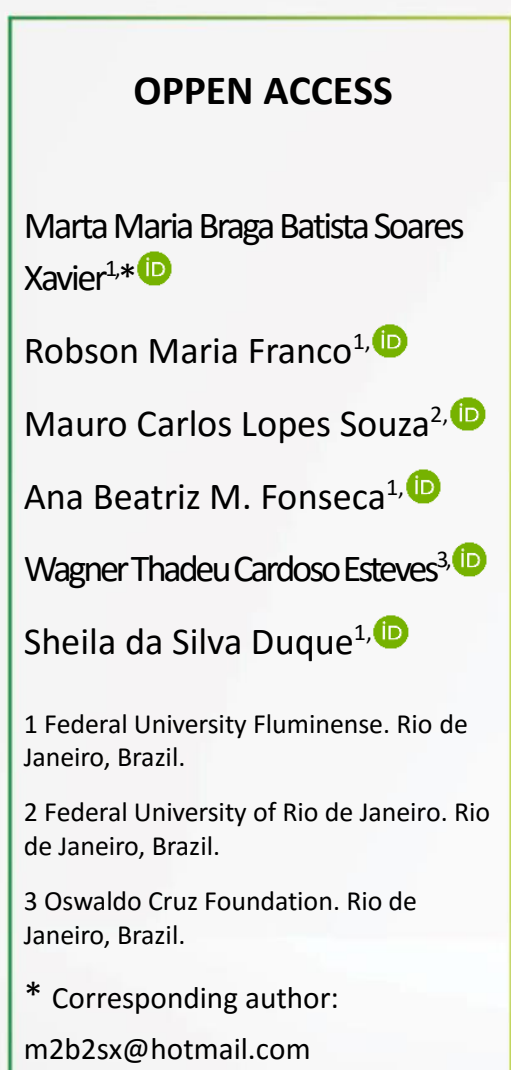

\section{Additional information}

Received: 08/08/2016

Accept: 08/26/2016

Published: 09/30/2016

Editor

Neila Mello dos Santos Cortez

Federal University of Pernambuco, Brazil.

neilacortez@yahoo.com.br

\section{Double blind peer review}

Reviews process

Prot. 1162016 R01

Prot. $1162016 R 02$

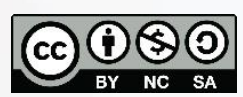

JBFS all rights

Copyright: (C) 2016
ID JBFS1162016

DOI 10.18067/jbfs.v3i3.116

\section{ABSTRACT}

The present study aimed to evaluate the efficiency of the irradiation process in the control of Enterococci spp. and Escherichia coli in chilled chicken heart samples acquired in an industry located in the West Zone of Rio de Janeiro, Brazil, using irradiation doses of $1.5 \mathrm{kGy}, 3,0 \mathrm{kGy}$ and 4.5 $\mathrm{kGy}$. These microorganisms are related to fecal contamination, and are indicators of the sanitary processing conditions of the foodstuffs. The bacteriological analyses were conducted applying the methodologies and standards recommended by Brazilian norms resolution no. 12 (BRASIL, 2001) and instruction no. 62 (BRASIL, 2003) Regarding Escherichia coli, no statistically significant difference among the four groups (control, $1.5 \mathrm{kGy}$, $3.0 \mathrm{kGy}$ and $4.5 \mathrm{kGy}$ ) was observed ( $p>0.05$ ). The Most Probable Number (MPN) for Enterococci spp. was not proven in the investigated samples. Thus, the Co60 gamma irradiation process was effective in eliminating Escherichia coli, and the lowest dose, of $1.5 \mathrm{kGy}$, was enough to abolish this enteropathogen from the evaluated samples.

Keywords: Food irradiation. Chicken heart. Enterococci spp. Escherichia coli Public health.

\section{RESUMO}

Objetivou-se na elaboração deste trabalho avaliar da eficiência do processo de irradiação no controle de Enterococcus spp. e de Escherichia coli em amostras de coração de frango refrigerado, adquiridas numa indústria na Zona Oeste do Rio de Janeiro, empregando-se as doses de 1,5 kGy, 3,0 kGy e 4,5 kGy. Estes microrganismos encontram-se relacionados à contaminação fecal de carne e miúdos de frango como também da avaliação das condições higiênico-sanitárias inerentes ao processamento. Para realização das análises bacteriológicas foi aplicada a metodologia e padrões preconizados pela Resolução RDC $n^{\circ} .12$ (BRASIL, 2001) e da Instrução Normativa $n^{\circ} .62$ (BRASIL, 2003). Quanto aos resultados estatísticos obtidos na pesquisa e controle de Escherichia coli, não foi evidenciada diferença estatisticamente significativa entre os quatro grupos analisados, controle e irradiados ( $p>0,05)$. O Número Mais Provável (NMP) de Enterococcus spp. não teve sua presença comprovada nas amostras analisadas. Concluiu-se, com a elaboração desta pesquisa, que o processo da irradiação gama Co60 com que a menor dose empregada, 1,5 KGy foi eficiente na eliminação das bactérias Escherichia coli nas amostras analisadas.

Palavras-chave: Irradiação de alimentos. Coração de frango. Enterococcus spp. Escherichia coli. Saúde coletiva. 


\section{INTRODUCTION}

Brazil's poultry industry began the year of 2016 breaking several records, including production and exporting of chicken products. Chicken meat, consolidated as the fourth item of the national export portfolio, achieved, in 2015, the three best monthly results in the history of the sector's exports. ${ }^{1}$

The importance of studying contamination of chicken giblets and meat is highlighted by the fact that these products are an important source of high quality protein, rich in essential amino acids, vitamins and minerals, and consumed in large scale in Brazil and throughout the world, being the highest preference percentage of the world's slaughter of animals when compared to beef and pork. ${ }^{2-4}$

However, it is worth mentioning that the Brazilian health legislation that determines the microbiological standards for food, the Resolution no. 12 (BRASIL), ${ }^{5}$ as stated in item 5 for meat/meat products, sub-clause $c$, poultry giblets, only follows the standard for coliforms at $45{ }^{\circ} \mathrm{C} \mathrm{g}^{-1}$ (fecal/thermophilic coliforms), and no maximum permissible value is found for other organisms, such as Enterococci spp. in these products. In such cases, Annex II of this same norm is taken into account regarding pathogenic microorganisms, which only states that "products or batches (indicative or representative sample, respectively), unfit for human consumption by presenting [...] a pathogenic microorganism or toxin represent severe hazards to consumer health".

Irradiation of foodstuffs is an effective method does not produce environmental waste and is accepted employed and its use is authorized in more than 50 countries worldwide and for various types of food products. ${ }^{6}$

Food irradiation is being considered as an important technological process, not only in ensuring safety but also in extending the shelf-life of chicken meat and meat products, ready to eat products, including the various ethnic foods from every continent of this planet. ${ }^{3,7-10}$

In this regard, ionizing irradiation is a safe and proven physical food conservation, used to reduce or eliminate pathogenic microorganisms, in turn controlling the microbiological quality of several foodstuffs and reducing the risk of foodborne illness. ${ }^{4,11-13}$

Thus, in this setting, the present study aimed to evaluate the efficiency of gamma radiation (Co60) with respect to bacteriological parameters in chilled chicken heart (Gallus gallus) samples, to evaluate the presence of Escherichia coli and Enterococci spp., microorganisms indicative of the production/handling sanitary conditions of raw materials that are responsible for several foodborne illnesses. ${ }^{14-16}$

\section{MATERIAL AND METHODS}

Chilled chicken hearts were purchased from an industry located in the West Zone of Rio de Janeiro. The giblets were randomly selected taking into account the production date closest to the beginning of the analyses. The samples were then transported and maintained chilled at a maximum of $7^{\circ} \mathrm{C}$ in an isothermal container during all steps of the experiments. ${ }^{17}$

They were subsequently placed in plastic ziplock bags and transported on ice to the Nuclear Instrumentation Laboratory/Federal University of Rio de Janeiro (LIN/UFRJ) where three groups were submitted to the gamma irradiation process (Co60) at $1.5 \mathrm{kGy}, 3.0 \mathrm{kGy}$ and $4.5 \mathrm{kGy}$. Control samples were not irradiated and remained on ice during this step. After irradiation, the control and irradiated samples were then transported to the Bacterial Zoonosis Laboratory at the Oswaldo Cruz Institute (Oswaldo Cruz Foundation) for the bacteriological analyses regarding E. coli and Enterococci spp.

The Most Probable Number (MPN) miniaturization technique of total and fecal coliforms for $E$. coli was performed using the Fluorocult $\mathrm{LMX}{ }^{\circledR}$ Quick Method, ${ }^{18}$ while the Most Probable Number (MPN) for Enterococci spp. was performed using the Quick ChromoCult ${ }^{\circledR}$ Broth diagnostic assay ${ }^{19}$ for each chilled chicken heart sample, both irradiated at the three doses and controls, by serial dilutions from $10^{-1}$ to $10^{-8}$.

The statistical analyses were conducted using the SPSS version 18 software package. The non-parametric Friedman test was applied to compare the four groups (controls and three doses) regarding research technique and 
bacteriological enumeration techniques, with a significance level of $0.05(5 \%)$.

\section{RESULTS AND DISCUSSION:}

No significant difference between samples regarding positivity in the control group were observed for E. coli $(\mathrm{p}=1.000)$. In addition, no significant difference between the samples subjected to the irradiation process, at $1.5 \mathrm{kGy}, 3.0 \mathrm{kGy}, 4.5 \mathrm{kGy}$ regarding the MPN for E. coli were observed $(p=1.000)$.

Concerning the midline enumeration of Escherichia coli from the four groups, a four log cycle decrease on the days the analyses were performed was observed during the first week, while during the second week elimination of the microbiota occurred and, finally, on the third week, a three logarithmic cycle decreases was observed, demonstrating the efficiency of the irradiation process, with MPN values smaller than $<3$ in the irradiated groups, being considered zero for the statistical analyses (Figure 1).

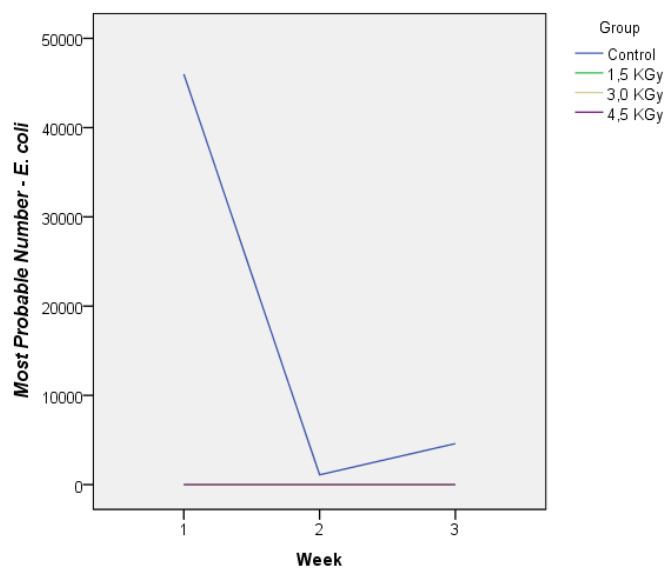

Figure 1. Results observed in E. coli NMP control during the three weeks of the experiment, at CCAMP / LABZOO / IOC / FIOCRUZ, on January 2016.

Similarly, to the results observed herein when comparing the control group to the irradiated samples, Bánáti et al. ${ }^{20}$ using two $E$. coli control methods in chicken breast, of irradiation with an electron beam associated to $\mathrm{pH}$, reported that a $2.0 \mathrm{kGy}$ dose reduced the Escherichia coli population from three to four log cycles in the irradiated chicken meat samples.

Another study, conducted by Xavier et al., ${ }^{21}$ on chilled chicken heart samples regarding the efficiency of another gamma irradiation process (Cs137) with the same doses applied herein albeit associated with cooling observed logarithmic decreases in the bacterial count of the samples, as well as increases in product shelf-life.
In the study conducted by Adu-Gyamfi et al.,. ${ }^{22}$ was also reported the microbiological quality of chicken at different retail outlets (supermarkets, local markets and farms) in Accra was investigated, and $\mathrm{D}_{10}$-values of $E$. coli was determined when the samples were treated with irradiation doses rates of between $1.151-1.089 \mathrm{kGy} \mathrm{h}^{-1}$ using a Cobalt-60 source. This study has revealed the $D_{10^{-}}$ values of Escherichia coli were 0.22 and 0.32 kGy in refrigerated and frozen chicken respectively. In this present study, it was also revealed that E. coli had a significantly lower value, even to its total elimination, when irradiated at $1.0 \mathrm{KGy}$.

Pelicia et al., ${ }^{23}$ on the other hand, evaluated the ability of gamma radiation to reduce Escherichia coli populations in chicken breast meat, and observed that a 2,0 kGy, 4,0 kGy and 8.0 kGy were sufficient to eliminate fecal coliforms in the meat samples, while the results obtained herein, with lower doses (1.5 kGy, 3.0 kGy and $4.5 \mathrm{kGy}$ ), were more efficient in reducing/eliminating microorganism counts. Some authors, as Al-Bachir and Othman ${ }^{24}$ and Torgby-Tetth et al. ${ }^{4}$ state that ionizing irradiation destroyed these microorganisms in meat chiken. Gamma irradiation is effective in reducing viable bacteria and eliminating potential pathogens such as Escherichia coli from chicken, these results corroborate those obtained in this experiment.

Regarding the presence of Enterococci spp., all samples (controls, $1.5 \mathrm{kGy}, 3.0 \mathrm{kGy}$ and $4.5 \mathrm{kGy}$ ) were negative for this microorganism, regardless of the irradiation dose (Figure 2). In addition, no significant differences between the experiment weeks, samplings and sample analyses were observed regarding for presence of Enterococci spp. using a 0.05 significance level $(p=1.000)$.

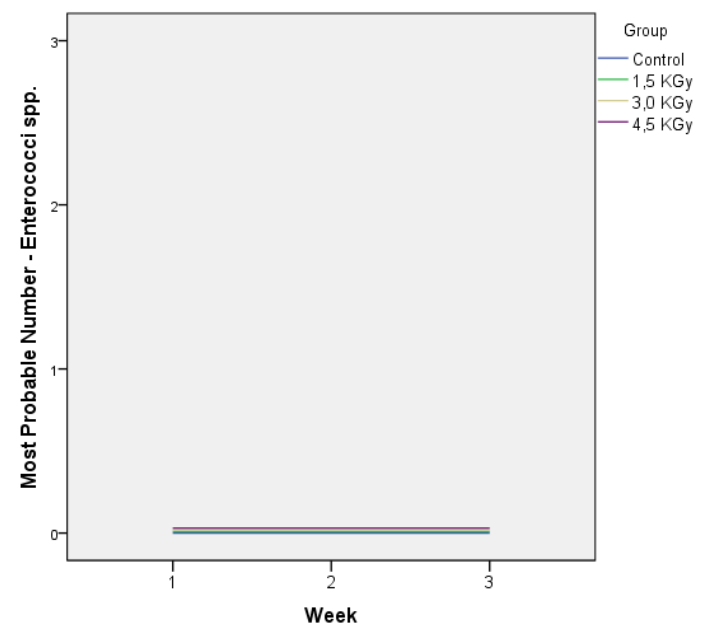

Figure 2. Results observed in the control Enterococci spp. NMP during the three weeks of the experiment, at CCAMP / LABZOO / IOC / FIOCRUZ, on January 2016. 
On the other hand, considering the analyses carried out by Tabatabaei Yazdi and Jouki, ${ }^{25}$ Enterococci spp. counts in meat ostrich irradiated with $3.0 \mathrm{kGy}$, were shown to increase with product storage time. The same was reported by Henry et al. ${ }^{26}$ for turkey meat, who noted that, although the irradiation was effective in reducing microorganisms, observed increases in Enterococci spp. in the foodstuffs during storage. This was also observed by Xavier et al. ${ }^{21}$ while analyzing irradiated chilled chicken hearts with the same doses applied herein, of decreases/elimination in microorganism counts, which increased during storage. However, at the $4.5 \mathrm{kGy}$ dose, the count value was $<3$, or equal to zero, thus considered as zero for the statistical analyses.

Another study carried out by Soares et al. ${ }^{27}$ with raw scallop muscle and gonads irradiated with Cs137 at 2.0 and $5.0 \mathrm{kGy}$ observed no positive counts for this microorganism either in the control group or the irradiated samples, similarly to what was observed herein, in which all the chilled chicken heart samples irradiated with Co60 were negative for Enterococci spp., regardless of the irradiation dose, as well as the controls.

\section{CONCLUSIONS}

Gamma Co60 irradiation when applied to chilled chicken heart was effective in eliminating the $E$. coli population initially present in the analyzed samples. Comparisons to the literature indicated that a $1.5 \mathrm{kGy}$ dose would be sufficient in this regard. The presence of $E$. coli in the evaluated samples indicates the need to improve the hygienic-sanitary standards in the processing line of chicken giblets, as well as continued health education for handlers, employees and consumers on the dangers and risks to which they are submitted. Enterococci spp. were absent from all investigated samples, controls (non-irradiated) and irradiated samples at all three doses.

\section{ACKNOWLEDGMENTS}

Acknowledgments to Coordenação de Aperfeiçoamento de Pessoal de Nível Superior (CAPES), to Departamento de Engenharia Nuclear da COPPE, Laboratório de Instrumentação Nuclear, Centro de Tecnologia, Universidade Federal do Rio de Janeiro, and specially to Coleção de Campylobacter, Laboratório de Zoonoses Bacterianas, IOC/ FIOCRUZ.

\section{AUTHOR CONTRIBUITION}

The Professor Dr. MCLS accompanied the studies of nuclear radiation, irradiation of samples and participated in the sequence alignment and drafted the manuscript. The researchers from CCAMP / LABZOO / IOC / FIOCRUZ, Dr. SSD e Dr. WTCE, for using this laboratory, and supporting of samples analysis, as well contributed to the suggestion of scientific references. Professor Dr. ABMF was responsible for the statistical analysis of the results of the present study. elaboration of the graphics with statistical results. The author, MMBBSX for carrying out the article, the review and approval of the final manuscript proof. Professor Dr. RMF as project advisor and reviewer activities.

\section{COMPETING INTERESTS}

The authors declare there are no competing interests.

\section{FUNDING}

The authors received no funding this work.

\section{HOW TO CITE THIS ARTICLE}

\section{ABNT}

XAVIER, Marta Maria Braga Batista Soares et al. Effect of gamma irradiation (C060) in the control of Enterococci spp. and Escherichia coli in chilled chicken (Gallus gallus) heart. Journal of bioenergy and food science,. Journal of bioenergy and food science, v.3, n.3, p.124-129, 2016. DOI:10.18067/jbfs.v3i3.116

\section{APA}

Xavier, M., Franco, R., Souza, M., Fonseca, A., Esteves, W., \& Duque, S. (2016). Effect of gamma irradiation (Co60) in the control of Enterococci spp. and Escherichia coli in chilled chicken (Gallus gallus) heart. Journal Of Bioenergy And Food Science, 3(3), 124-129. DOI:10.18067/jbfs.v3i3.116.

\section{REFERENCES}

1. ASSOCIAÇÃO BRASILEIRA DE PROTEÍNA ANIMAL (ABPA). Avicultura e Suinocultura do Brasil: Produção e Exportação; Previsões para 2015 e 2016. Publicado em 09 de dezembro de 2015. Available in: <Associação\%20Brasileira\%20de\%20Proteína\%

20Animal \% 20\%20ABPA.html>. Acessed on: 06 jan. 2016.

2. REVISTA AVICULTURA BRASIL. Carne de frango, unanimidade que vai do Norte ao Sul do Brasil. Pesquisa encomendada pela UBABEF ao Centro de Assessoria e Pesquisa de Mercado (CEAP). Revista Avicultura Brasil, n.1, p. 8-14, 2012.

3. SARWAR, A.; ULLAH, S.; ULLAH, F.; KHAN, M.; ULLAH, W. Effect of Gamma Irradiation on Microbial Quality of Red and Poultry Meat Sold and Processed in Peshawar, 
Pakistan. European Academic Research, v.1, n.12, p.5851-5861, 2014.

4. TORGBY-TETTEH, W.; ADU-GYAMFI, A.; ODAI, B. T.; APPIAH, V. Combined effect of irradiation and frozen storage on survival of viable bacteria and inoculated Escherichia coli in chicken. Journal of Food and Nutrition Sciences, v.2, n.3, p.53-57, 2014. DOI 10.11648/j.jfns.20140203.11

5. BRASIL. Ministério da Saúde. Agência Nacional de Vigilância Sanitária (ANVISA). Resolução RDC no 12, de 2 de janeiro de 2001. Aprova o Regulamento Técnico sobre padrões microbiológicos para alimentos e seus Anexos I e II. Publicado no Diário Oficial [da] República Federativa do Brasil, Brasília, DF, p. 45 - 53, seção 1, de 10 de janeiro de 2001.

6. CUTRUBINIS, C. D.; SAVUA, D.; ELISABETA; S. C.; MIHAIA, R.; SECUB, M.; PONATTA, C. Preliminary study on detection of irradiated foodstuffs from the Romanian market. Radiation Physics and Chemistry, v.76, p.14501454, 2007. DOI 10.1016/j.radphyschem.2007.02.049

7. AL-BACHIR, M.; FARAH, S.; OTHMAN, Y. Influence of gamma irradiation and storage on the microbial load, chemical and sensory quality of chicken kabab., Radiation Physics and Chemistry, v.79, p.900-905, 2010.DOI 10.1016/j. radphyschem.2010.02.010

8. AL-BACHIR, M. Effect of gamma irradiation on the microbial load, chemical and sensory properties of kubba: prepared chilled meal. Food Technology, v. 37, n. 2, p. 82-92, 2013.

9. INAMURA, P. Y.; UEHARA, V. B.; CHRISTIAN A.H.M. TEIXEIRA, C. A. H. M.; DEL MASTRO, N. Mediate gamma radiation effects on some packaged food items. Radiation Physics and Chemistry. (2012), DOI 10.1016/j.radphyschem.2012.01.022

10. KIM, I. S.; JO, C.; LEE, K. H.; AHN, D. U.; KANG; S. N. Effect of low-level gamma irradiation on the characteristics of fermented pork sausage during storage. Radiation Physics and Chemistry, v.81, n.4 p.466-472, 2012. DOI 10.1016/j.radphyschem.2011.12.037

11. MENDONCA, A. F. Inactivation by irradiation. In: JUNEJA, V.; SOFOS, J. Control of Foodborne Microorganisms. ed. Marcel Dekker Inc., New York, NY. 2002. p. 75-103.

12. MIRANDA, Z. B. Irradiação de alimentos: mito ou realidade? Animal Business Brasil, n. 2, p. 56-65, 1 de mar de 2012.

13. MOLINS, R. A. Irradiación de los alimentos: principios y aplicaciones. Zaragoza: Editorial Acribia, 2001. $490 \mathrm{p}$.

14. NEWELL, D. G.; KOOPMANS, M.; VERHOEF, L.; DUIZER, E.; AIDARA-KANE, A.; SPRONG, H.; OPSTEEGH, M.; LANGELAAR, M.; THREFALL, J.; SCHEUTZ, F.; VAN DER GIESSEN, J.; KRUSE, $H$. Food-borne diseases - The challenges of 20 years ago still persist while new ones continue to emerge. International Journal of Food Microbiology, n.139, p.s3-s15, 2010. DOI 10.1016/j.ijfoodmicro.2010.01.021

15. FRANCO, B. D. G. M.; LANDGRAF, M. Microbiologia dos alimentos. Col. Maria Teresa Destro. São Paulo: Ed. Atheneu, 2008. $182 \mathrm{p}$.

16. FRANCO, R. M. Agentes etiológicos de doenças alimentares. Niterói: Editora da UFF (Coleção Didáticos), 2012. 120 p.

17. BRASIL. Ministério da Agricultura Pesca e Abastecimento (MAPA). Portaria no 304, de 22 de abril de 1996. Os estabelecimentos de abate de bovinos, bubalinos e suínos, somente poderão entregar carnes e miúdos, para comercialização, com temperatura de até 7 (sete) graus centígrados. Publicado no Diário Oficial da União, Brasília, DF, de 23 de abril de 1996.

18. MANTILLA, S. P. M.; SANTOS, E. B.; FREITAS, M. Q; VITAL, H. C.; MANO, S. B.; FRANCO, R. M. Refrigerated poultry breast fillets packed in modified atmosphere and irradiated: bacteriological evaluation, shelf life and sensory acceptance. Brazilian Journal of Microbiology, v.43, n.4, p.1385-1392, 2012. DOI 10.1590\%2FS1517838220120004000020

19. VIEIRA, J. P.; FREITAS, M. A. M.; FONTENELLE, G.; SILVA, T. J. P.; FRANCO, R. M. Avaliação da eficiência da radiação gama na carne resfriada de jacaré-do-pantanal (Caiman crocodilus yacare) pela enumeração de Enterococci spp. Revista Higiene Alimentar, v.25, n.194/195, 2011.

20. BÁNÁTI, D.; FIELDING, L. M.; GRANDINSON, A. S.; COOK, P. E. The effect of combinations of irradiation and $\mathrm{pH}$ on the survival of Escherichia coli on chicken meat. Letters in Applied Microbiology, v.16, p. 239-242, 1993. DOI 10.1111/j.1472-765X.1993.tb01408.x

21. XAVIER, M. M. B. B. S.; SOUZA, A. L. M.; XAVIER, P. M. B. B. S.; VITAL, H. C.; FRANCO, R. M.; MIRANDA, Z. B. Efeitos da irradiação gama em coração de frango resfriado: análises bacteriológicas. Revista Higiene Alimentar, v. 25, n.194/195, 2011.

22. ADU-GYAMFI, A.; TORGBY-TETTEH, W.; APPIAH, V. Microbiological Quality of Chicken Sold in Accra and Determination of D10-Value of E. coli. Food and Nutrition Sciences, v.3, p. 693-698, 2012. DOI 10.4236/fns.2012.35094

23. PELICIA, K.; GARCIA, E. A.; MOLINO, A. B.; SANTOS, G. C.; VIEIRA FILHO, J. A.; SANTOS, T. A.; BERTO, D. A. Chicken Meat Submitted to Gamma Radiation and Packed with or without Oxygen. Brazilian Journal of Poultry Science. v. 17, n. 2, p. 255-262, 2015. DOI 10.1590/1516-635x1702255-262

24. AL-BACHIR, M.; OTHMAN, Y. Use of irradiation to control microorganisms and extend the refrigerated 
market life of chicken sausage. Innovative Romanian Food Biotechnology, v. 13, p: 63-70, 2013.

25. TABATABAEI YAZDI, F.; JOUKI, M. Gamma irradiation effects on microbial decontamination of ostrich meat. Scientific Journal of Microbiology. v. 1, n. 5, p. 119-125. 2012.

26. HENRY, F. C.; SILVA, T. J. P.; FRANCO, R. M.; FREITAS, M. Q.; JESUS, E. F. O. Effect of gamma radiation on frozen turkey breast meat quality. Journal of Food safety. v.30, p.615-634, 2010. DOI 10.1111/j.17454565.2010.00229.x

27. SOARES, I. C.; MESQUITA, E. F. M.; FRANCO, R. M.; VITAL, H. C.; RUBIÃO, C. A. Análise bacteriológica de músculo e gônadas de vieira, Nodipecten nodosus (Mollusca: Bivalvia), congelados e irradiados. Brazilian Journal of Veterinary Research and Animal Science, São Paulo: v. 49, n. 1, p. 24-29, 2012. 